\title{
Após junho de 2013:
coletivos estético-políticos na guerrilha do sensível \\ Thiago Fernandes ${ }^{1}$ \\ DOI 10.20396/eha.vil4.3347
}

Em junho de 2013, uma série de manifestações tomaram as ruas do Brasil. A princípio como movimentos apartidários, sem hierarquia, organizados nas redes sociais, combatendo o aumento dos preços das tarifas de ônibus. Tal cenário já vinha sendo anunciado com a greve dos professores da rede pública de diversos estados em 2011 e com a greve dos bombeiros em 2012. Mas as manifestações de 2013, também conhecidas como "jornadas de junho", conduzidas principalmente por jovens estudantes, tomaram proporções gigantescas, sendo consideradas um dos maiores movimentos políticos da história do país.

No contexto das manifestações, surgiram coletivos estético-políticos que, diferentemente dos coletivos brasileiros que se proliferaram na virada do século XXI, contaram com as redes sociais como elementos essenciais para sua articulação, servindo como instrumento de organização e troca - assim como também foram para organizadores dos protestos. Outra questão que marca a diferença entre os coletivos dos anos 2000 e os mais recentes é que, enquanto os primeiros, em sua maioria, surgiram movidos pela insatisfação com o sistema de arte, propondo meios de autogestão e modos alternativos de exposição, o que motiva os grupos mais recentes é a vontade de articulação política, seu direcionamento crítico a alvos bem-definidos, e o espírito de tomada dos espaços públicos pelo povo que se consolidou com as manifestações de 2013. "Ocupação", não por acaso, é uma das palavras mais repetidas pelos manifestantes, que de lá para cá vêm ocupando as ruas, edifícios institucionais, escolas e reitorias de universidades.

Coletivos que misturam arte e ativismo não são novidade. São memoráveis as ações do grupo 3Nós3, surgido em São Paulo no final da década de 1970, e de alguns coletivos dos anos 2000, como o Frente 3 de Fevereiro - que propõe ações contra o racismo estrutural no Brasil - e o Contrafilé - que em 2004 realizou o Monumento à Catraca Invisível, promovendo reflexões a respeito das diversas formas de controle invisível às quais estamos sujeitos cotidianamente e sobre a igualdade de 
acesso à cidade -, para citar apenas alguns exemplos. Mas não se pode deixar de notar que houve um movimento crescente de coletivos estético-políticos desde 2013.

Ações estético-políticas são definidas por Jorge Vasconcellos e Mariana Pimentel como práticas (mais que conceitos) que se colocam diante das urgências da atualidade. Elas surgem na contramão do mercado de arte, tomando dimensão de contra-arte e de proposições anticapitalistas, além de aspirar ao anonimato numa sociedade que prima pela celebridade. Embora tenham forte diálogo com as artes performáticas ou performativas, tais ações podem ser realizadas por qualquer pessoa, independentemente de uma formação artística:

Uma ação estético-política é arte sem artista. Mesmo que sejam artistas que a realizem, isso pouco importará, pois o que importa é justamente quando se instaura, por intermédio da ação, uma zona de indiscernibilidade, uma zona de risco (não de perigo, que fique claro) que não nos permite saber de fato do que se trata: arte ou protesto? arte ou crime?... uma ação estético-política é borda, fronteira de risco, abismo... amor fati! ${ }^{2}$

Essas propostas configuram meios de partilhar o sensível, produzindo "maneiras de fazer que intervêm na distribuição geral das maneiras de fazer e nas suas relações com maneiras de ser e formas de visibilidade". ${ }^{3}$ Com a noção de partilha do sensível, Jacques Rancière compreende que a política e a estética têm uma raiz em comum, pois ambas trabalham no regime da visibilidade. $A$ política confere visibilidade a certos grupos e a visibilidade é uma categoria trabalhada pela estética. Quando questionamos quem pode falar e para quem se fala, poderíamos também questionar quem pode criar imagens e para quem elas se dirigem. ${ }^{4}$

Para Rancière, a base da política está no dissenso, e não no consenso. Ou seja, a essência da política não é o entendimento entre as partes, mas os conflitos, as divergências. A falta de consenso também é uma característica da arte contemporânea. Na contemporaneidade não há critérios fixos para se estabelecer o que é e o que não é arte, como também não há parâmetros para dizer o que é uma arte boa ou ruim. A arte contribui com o dissenso, com a quebra do status quo. Ela questiona certezas partilhadas por uma comunidade cujo corpo social é fragmentado e, justamente por reconhecer essa fissura, a arte, como a política, torna visível o que não é, o que está à margem, o que fica de fora de um espaço previamente definido como "comum". O dissenso se dá quando ações de sujei-

\footnotetext{
2 VASCONCELLOS, Jorge; PIMENTEL, Mariana. O que é uma ação estético-política? (um contramanifesto). In: Vazantes, Revista do Programa de Pós-Graduação em Artes do Instituto de Cultura e Artes, Ceará, n. 1, pp. 191-200, 2017, p. 194.

3 RANCIÈRE, Jacques. A partilha do sensível: estética e política. São Paulo: EXO experimental org., Ed. 34, 2005, p. 17.

4 RANCIĖRE, Jacques. O espectador emancipado. São Paulo: Editora WMF Martins Fontes, 2012.
} 
tos que não eram dadas como interlocuções passam a aparecer e a serem percebidas. Atuando contra estratégias homogeneizadoras e consensuais, que tentam destituir conflitos inerentes à cidade e à vida cotidiana - criando imagens de espaços apolíticos -, a arte opõe um mundo comum a um outro, explicitando esses dissensos que incomodam a quem quer manter o status quo. $A$ arte pode atuar numa "guerrilha do sensível", como propõe Paola Berenstein Jacques 5 , como forma de resistência e coexistência de diferenças, como mantedora ou criadora de tensões, enquanto os dispositivos de poder tentam estabelecer consensos silenciando outras narrativas e formas de existência.

Os coletivos estético-políticos pós-jornadas de junho tomam o espaço público como lugar do dissenso. Em primeiro lugar, fogem dos espaços institucionalizados da arte e confundem-se com a cidade. Além disso, criam ruídos na paisagem e nos meios de comunicação, alteram sua função e dão visibilidade a outras questões.

Dentre os coletivos estético-políticos que surgiram no contexto das jornadas de junho, um dos principais exemplos é o Projetação, que atuou nas manifestações armado com um projetor, um computador e um gerador. O grupo, formado por profissionais de diferentes áreas (como designers, comunicadores, arquitetos, médicos e advogados), projetou em fachadas de prédios, carros da polícia, árvores e quaisquer superfícies disponíveis frases de ordem sintonizadas com os gritos da multidão que caminhava pelas ruas (figura 1). Dessa maneira, o grupo se alinhava às propostas de ocupação e politização dos espaços públicos. Seguindo a lógica "faça você mesmo", o Projetação promoveu alguns "projetaços", propondo projeções simultâneas em várias cidades do Brasil como meio de ampliar o alcance e a força das mensagens. Registros das ações foram compartilhados no site do coletivo e em sua página no Facebook.

Em junho de 2015, dois anos após os grandes protestos das jornadas de junho, mas movido pelo mesmo espírito, surgiu o coletivo Seus Putos no contexto das manifestações realizadas no campus da Universidade do Estado do Rio de Janeiro, no Maracanã, que enfrentava graves problemas financeiros e de infraestrutura. Em sua primeira ação, realizada durante um protesto contra a violência no campus no dia 3 de junho de 2015, os integrantes do grupo vendaram suas bocas e cobriram seus corpos seminus com sangue cenográfico. Registros dessa performance circularam na grande mídia. Posteriormente o grupo realizou ações-vírus no circuito de arte, como uma "lavagem" de dinheiro na porta da Casa Daros e a distribuição de supostos preservativos dentro da ArtRio - a maior feira de arte do Rio de Janeiro - que continham dentro de suas embalagens, em vez do preservativo,

5 JACQUES, Paola Berenstein. Notas sobre espaço público e imagens da cidade. In: Arquitextos, São Paulo, n. 110.02, 2009. 
a mensagem: "PREVINA-SE: PORTO MARAVILHA GENTRIFICA". O grupo fazia referência ao projeto Porto Maravilha, da prefeitura do Rio de Janeiro, que reformou a Praça Mauá - onde acontecia a feira de arte-e toda a zona portuária da cidade, mas em contrapartida removeu moradias de pessoas de camadas populares da região.

Em mais um ato contra a gentrificação na Praça Mauá, integrantes do coletivo Seus Putos, no dia da inauguração do Museu do Amanhã, levantam placas e uma bandeira com a palavra "gentrificado", denunciando o processo que levou à remoção de pessoas empobrecidas daquela região e questionando os reais propósitos da construção do museu (figura 2). Num país que tem sua história recalcada, onde museus e bibliotecas são fechados por falta de investimento - ou ainda incendiados, como o caso do Museu Nacional em 2018-é realizado um projeto milionário cujo nome guarda ecos do "País do Futuro", como afirma Benjamin Moser. ${ }^{6}$ As reformas em questão faziam parte dos preparativos da cidade para receber os Jogos Olímpicos de 2016, ocasião que levou o Seus Putos a mais uma ação: a Operação Limpa-Alerj, na qual promoveram uma limpeza minuciosa da entrada da Assembleia Legislativa do Estado do Rio de Janeiro (Alerj), em data próxima à abertura dos Jogos Olímpicos na cidade (figura 3). Os artistas, de maneira exagerada, utilizavam máscaras cirúrgicas, luvas, mini-vassouras, pás, esponjas, espanadores e baldes - em sua maioria com a cor rosa -, reforçando o sentido irônico da ação. Além das ferramentas de limpeza estilizadas, também utilizavam seus característicos trajes provocativos e bem-humorados: Soraya Cyborgue (Rafa Ferreira), além de uma peruca rosa, tinha preso a seu corpo um pênis de borracha; Tertuliana Lustosa, enquanto segurava com uma mão uma escova, com a outra segurava uma metralhadora de brinquedo; Daniela Cassinelli ornamentava seu corpo com frutas falsas à la Carmen Miranda; Mateus A. Krustx vestia um colete refletivo; Lyz Parayzo cobria parcialmente seu corpo com uma fita adesiva prateada; Matheusa Passareli estava completamente vestida de rosa enquanto Ella Franz Rafa vestia uma camisa social branca, tipicamente associada ao gênero masculino. Dessa maneira, ainda que não fosse o tema central desses trabalhos, o coletivo Seus Putos abordava, por meio do apelo estético, questões de gênero, sexualidade e a quebra de padrões normativos, pautas recorrentes em coletivos estético-políticos pós-junho de 2013.

A performance do Seus Putos na Alerj parodiava a ação do coletivo japonês Hi-Red Center, quando em 1964, durante os Jogos Olímpicos de Tóquio, seus integrantes apareceram ajoelhados nas ruas da capital japonesa, vestindo jalecos brancos e máscaras cirúrgicas, esfregando as calçadas

6 MOSER, Benjamin. Autoimperialismo. São Paulo: Planeta, 2016. 


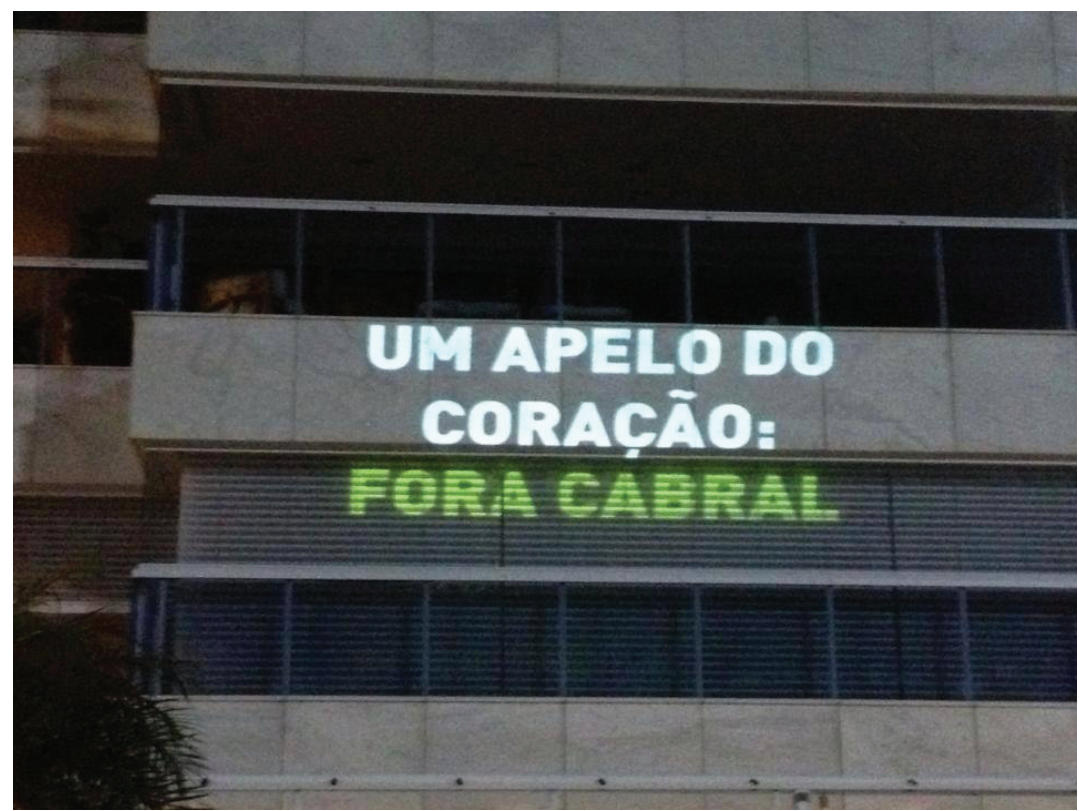

\section{[Figura 1]}

Coletivo Projetação, Ação contra o ex-governador do Rio de Janeiro, Sérgio Cabral, 2013.

Fonte: página do coletivo no Facebook.

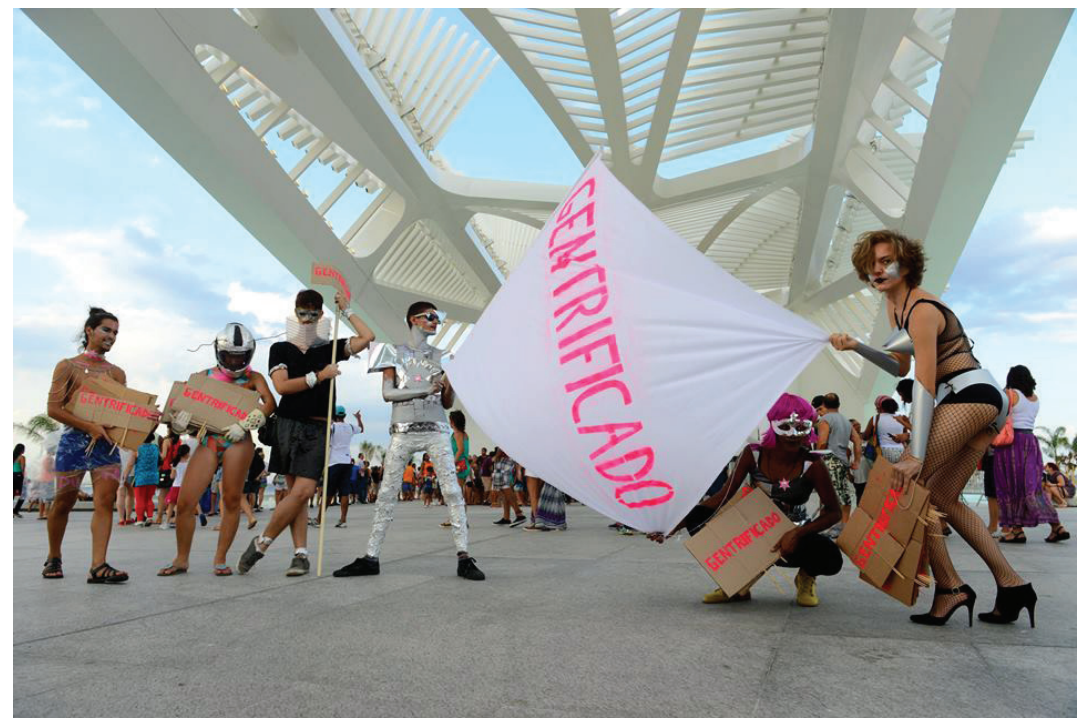

\section{[Figura 2]}

Coletivo Seus Putos, Putas Maravilhas em: Centrificado, 2015. fotográfico de Ceorge Magaraia.

Fonte: arquivo do grupo.

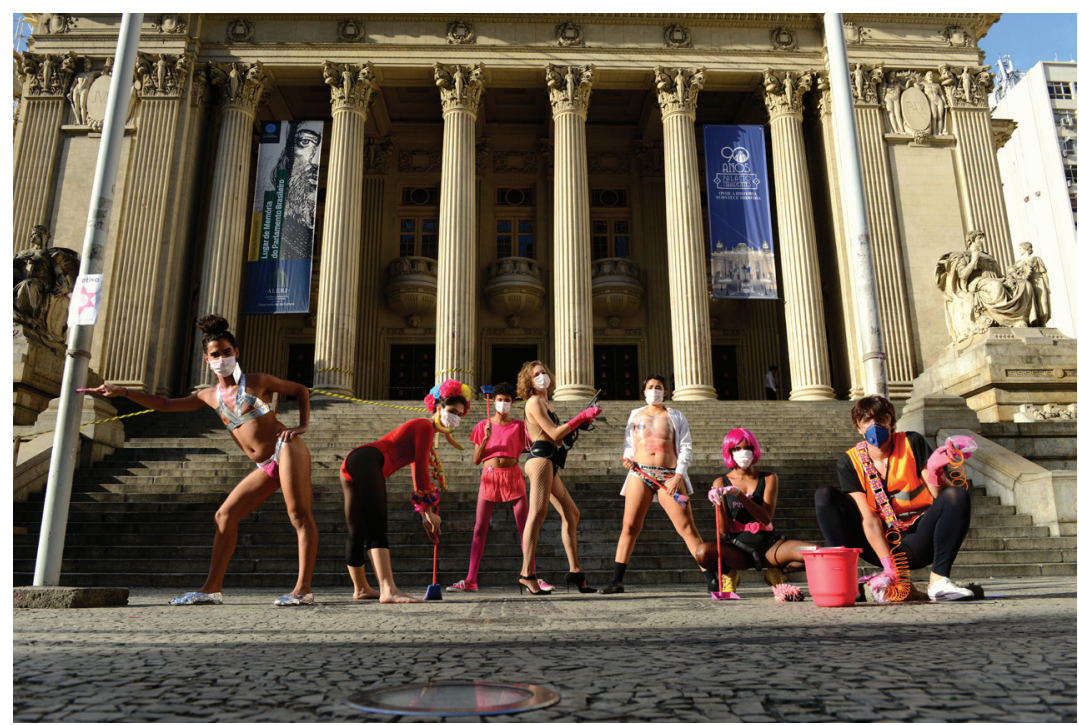

\section{[Figura 3]}

Coletivo Seus Putos, Operação Limpa-Alerj, 2016. Registro fotográfico de Ceorge Magaraia.

Fonte: arquivo do grupo 
da cidade, lançando mão até mesmo de escovas de dentes para o trabalho de limpeza urbana. A ação ironizava a obsessão por limpeza do governo japonês naquele momento em que os olhos do mundo se voltavam para o país e, num paralelo com o Rio de Janeiro olímpico, o coletivo Seus Putos realizou sua versão da performance, cujos registros em fotos e vídeos compuseram a mostra A emergência do contemporâneo: a vanguarda no Japão, 1950-1970, que aconteceu no Paço Imperial com curadoria de Pedro Erber. Registros dessa e das demais ações do coletivo também ganharam circulação em seu blog e sua página no Facebook.

O crescimento das manifestações de junho de 2013, contudo, também trouxe consequências como a ausência de uma pauta unificadora, o que favoreceu sua distorção pela grande mídia. Gritos contra o aumento das tarifas de ônibus cederam espaço a outras reivindicações, contra a corrupção, a violência policial, pelos direitos indígenas e de grupos minoritários, entre outros. O sociólogo Jessé de Souza, no livro A radiografia do golpe, conta como as jornadas de junho foram midiaticamente manipuladas. ${ }^{7}$ Segundo o autor, a mídia hegemônica, que à princípio se mantinha indiferente às manifestações ou fazia menções negativas utilizando a palavra "vandalismo", passou a apoiar e incentivar os protestos, como uma "explosão democrática do povo brasileiro". A cobertura midiática ${ }^{8}$, segundo Souza, federalizou os protestos com o objetivo de atingir a figura da presidenta Dilma Rousseff, colocando a pauta do fim da corrupção em posição central, no lugar do preço das tarifas de ônibus. Os protestos, antes criminalizados, passaram a ser definidos como pacíficos e a bandeira brasileira tornou-se seu símbolo, enquanto os tumultos passaram a ser atribuídos a uma "minoria de vândalos". Começaram a ganhar destaque rostos pintados, como no movimento "caraspintadas", que em 1992 exigia o impeachment do então presidente do Brasil, Fernando Collor de Melo. Se forjava a estética e a moral do movimento antigoverno-a perigosa estetização da política sobre a qual já alertava Walter Benjamin em 1935. ${ }^{9}$

Dilma, que gozava de uma taxa de aprovação de 79\% em março de 2013 (a mais alta que teve em seu governo), perdeu 27 pontos percentuais desde o início dos protestos. ${ }^{10}$ Embora reeleita em 2014, a polarização entre direita e esquerda se acentuou e discursos contra Dilma - que com a manipulação midiática tornou-se o rosto da corrupção -, contra o Partido dos Trabalhadores e contra qualquer governo de esquerda se difundiram pelo país. Novos protestos surgiram em 2016, desta

\footnotetext{
7 SOUZA, Jessé. A radiografia do golpe: entenda como e por que você foi enganado. Rio de Janeiro: LeYa, 2016.

8 O autor se baseia na cobertura do Jornal Nacional da Rede Globo.

9 BENJAMIN, Walter. A obra de arte na era de sua reprodutibilidade técnica. In: CAPISTRANO, Tadeu (org.). Benjamin e a obra de arte: técnica, imagem e percepção. Rio de Janeiro: Contraponto, 2012.

10 Ibid.
} 
vez movidos por grupos de direita exigindo o impeachment da então presidenta, que se consolidou em abril daquele ano.

Nesse contexto, surgiu o coletivo carioca Tupinambá Lambido, como resistência ao governo de Michel Temer, que entrou no lugar de Dilma assumindo uma agenda neoliberal e dando fim ao plano de governo da presidenta eleita. Composto por 7 artistas, o Tupinambá Lambido realiza ações de mídia tática, espalhando cartazes lambe-lambe pela cidade. Apropriando-se de uma mídia publicitária, o grupo veicula imagens que atacam diretamente o governo interino e grandes instituições beneficiadas pelo impeachment de Dilma - um golpe que se deu por um amplo acordo de interesses entre diversas elites, como afirma Souza, inconformadas com sua perda de privilégios enquanto as classes populares ascendiam durante os governos do Partido dos Trabalhadores.

O Tupinambá Lambido realizou sua primeira campanha em 2017. Nela destaca-se o cartaz O Colpe, que parodia o logotipo do jornal O Globo. O grupo também produziu a releitura de uma polêmica capa da revista Veja, que apresenta sobre um fundo vermelho uma ilustração da cabeça do ex-presidente Luiz Inácio Lula da Silva sangrando (figura 4). Na versão do Tupinambá Lambido, no lugar da cabeça de Lula figura a cabeça de Michel Temer. Tais imagens questionam a cobertura tendenciosa da grande mídia. Insistem, sobretudo, no uso na palavra "golpe", que vinha sendo combatido por conservadores - que ameaçaram até a ex-presidenta -, partindo da ideia de que se as pessoas não podem se referir a um fato, ele deixa de existir como tal. ${ }^{11}$ O Tupinambá Lambido, como coletivo de resistência, traz à memória os acontecimentos recentes e denuncia o golpe em questão por meio de suas imagens espalhadas massivamente, em cartazes de grandes dimensões espalhados em diversos pontos do Rio de Janeiro. O coletivo, como forma de dissenso, cria uma narrativa que segue na contramão daquela estabelecida pela mídia hegemônica.

Um cartaz apresenta a imagem da bandeira do Brasil que se reduz a uma pequena linha, quase desaparecendo no meio de duas grandes faixas pretas, evocando o espírito de luto pela democracia. A bandeira do Brasil, que se tornou símbolo dos movimentos conservadores que conduziram ao impeachment de Dilma, é apropriada novamente pelo coletivo num cartaz onde seu desenho é traçado pela transcrição do áudio de uma polêmica ligação vazada entre o ministro do planejamento de Temer, Romero Jucá, e Sérgio Machado (figuras 5 e 6).

Outros cartazes reproduzem o slogan propagado por grupos de resistência, que proclamavam "Amar sem temer" - fazendo um trocadilho com o sobrenome do então presidente -, enquanto 

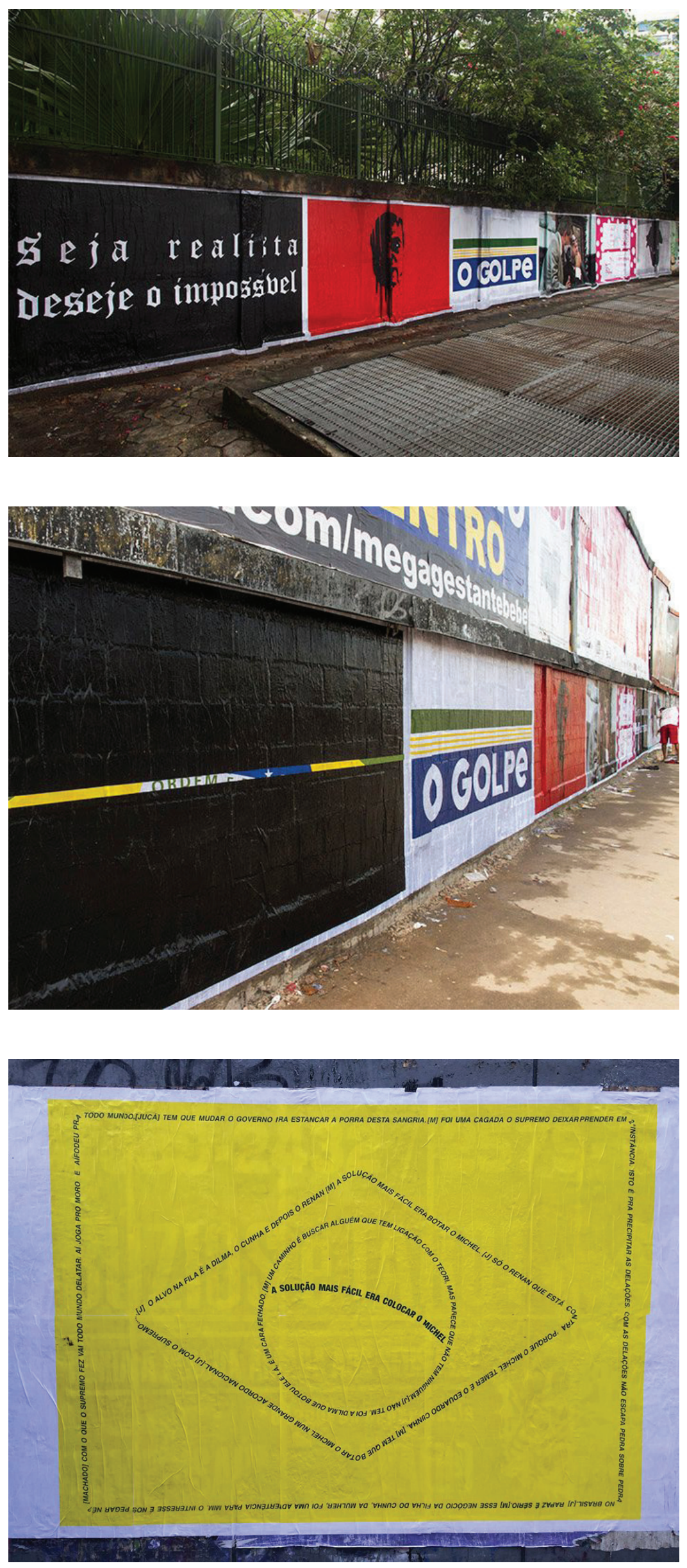

\section{[Figura 4]}

Tupinambá Lambido, 2017.

Fonte: arquivo do grupo.

\section{[Figura 5]}

Tupinambá Lambido, 2017. Fonte: arquivo do grupo

\section{[Figura 6]}

Tupinambá Lambido, 2017.

Fonte: arquivo do grupo 


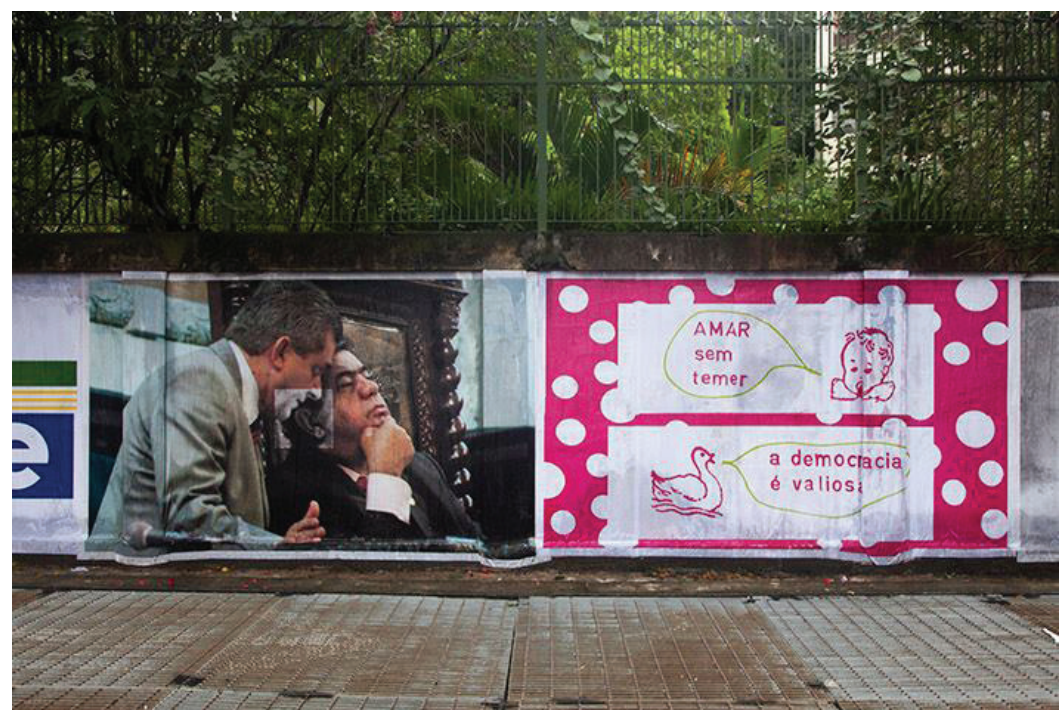

[Figura 7]

Tupinambá Lambido, 2017.

Fonte: arquivo do grupo

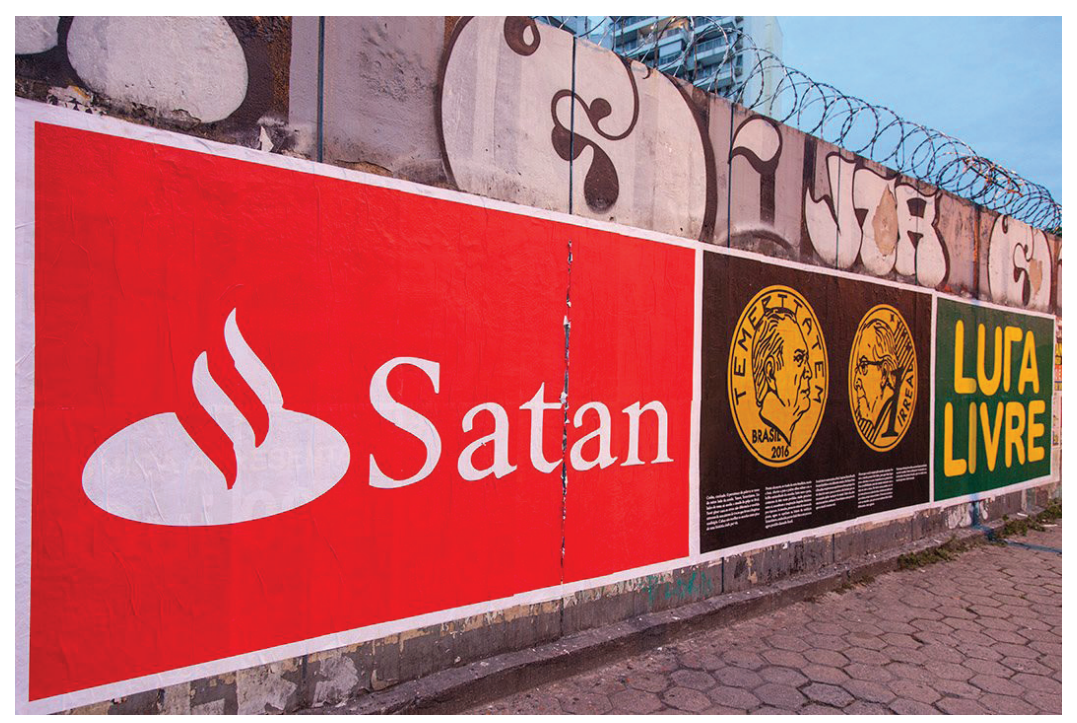

[Figura 8]

Tupinambá Lambido, 2017.

Fonte: arquivo do grupo

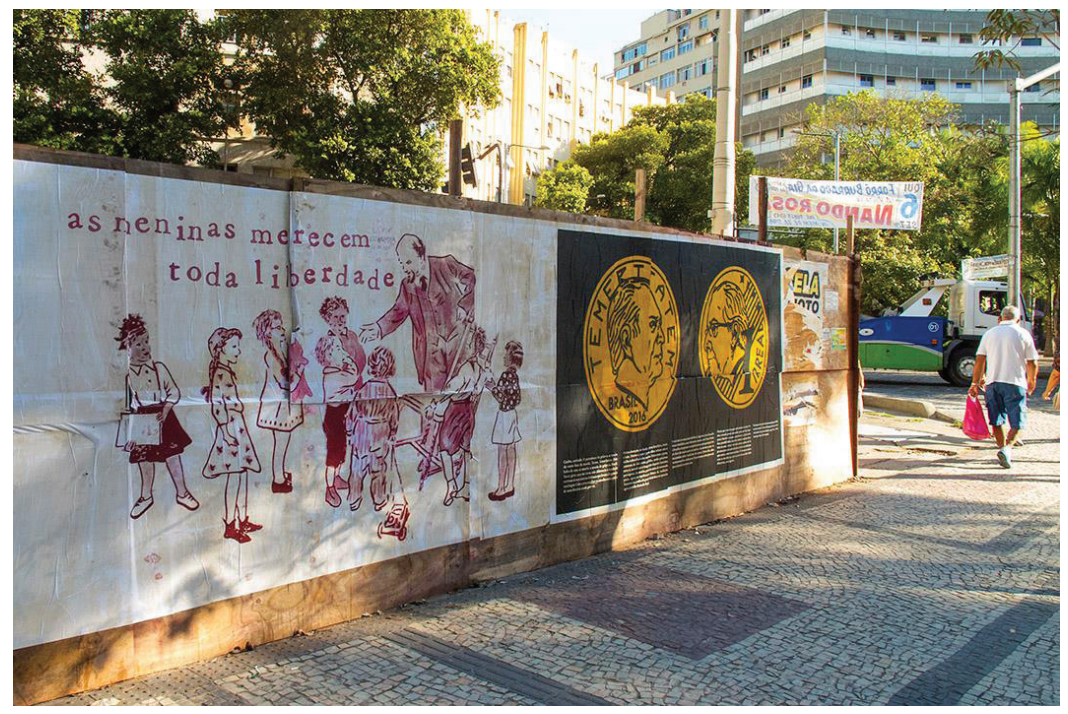

\section{[Figura 9]}

Tupinambá Lambido, 2017.

Fonte: arquivo do grupo 


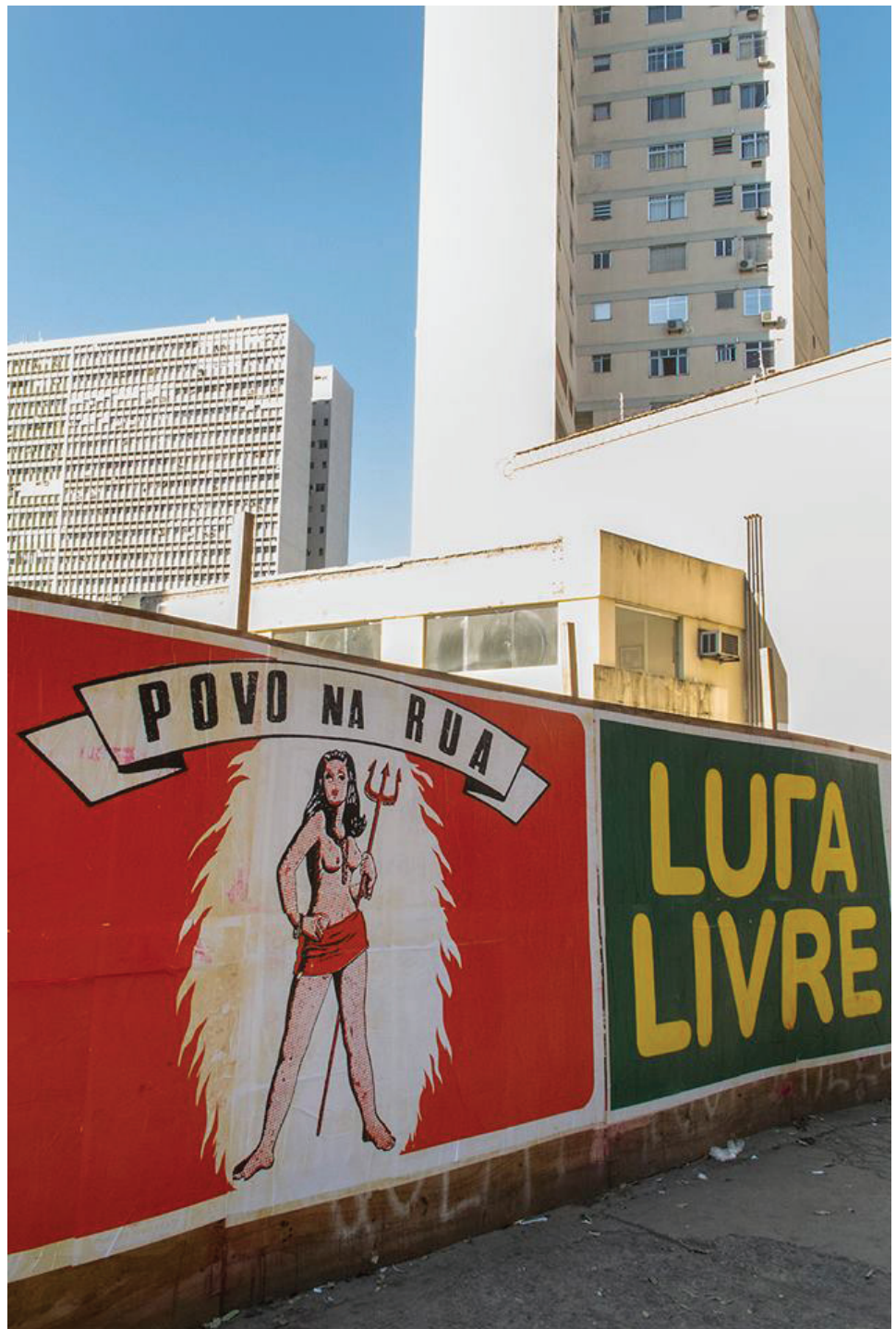

[Figura 10]

Tupinambá Lambido, 2017.

Fonte: arquivo do grupo. 
em outra imagem se lê a frase "Seja realista, deseje o impossível", que se tornou famosa ao ser grafitada em muros da França no histórico Maio de 1968. Outro cartaz, numa crítica mais direta, apresenta uma fotografia do então deputado Jorge Picciani, investigado em diferentes operações e finalmente preso em 2018. Figura facilmente reconhecida pelos transeuntes, Picciani é colocado no cartaz como uma alegoria à corrupção, e um detalhe da imagem é destacado: o ouvido de Picciani próximo à boca de outro político, que sussurra algo que não podemos compreender, mas podemos imaginar (figura 7).

Uma segunda campanha do grupo foi levada às ruas em meados de 2018, apresentando conteúdo mais heterogêneo (figuras 8, 9 e 10). Um cartaz com a palavra Satan parodia o logotipo do banco Santander, enquanto outro se apropria de um cartão postal da Baía de Guanabara rasgado ao meio, remendado e tingido com a cor vermelha, revelando um cenário distópico. Em contraponto ao projeto "Escola sem partido"12, um cartaz apresenta uma ilustração do revolucionário comunista russo Lenin, representado como um professor cercado de crianças, combinado com a legenda "As meninas merecem toda liberdade". As pautas feministas, representadas por essa imagem, também tiveram grande destaque no cenário político instaurado a partir das jornadas de junho de 2013 e, sobretudo, em 2018, com o assassinato brutal da então vereadora Marielle Franco - negra, de origem humilde, socióloga, feminista e defensora dos direitos humanos, que havia sido a quinta vereadora mais votada do Rio de Janeiro em 2016. Tal situação fez alavancar debates sobre direitos humanos e sobre o lugar da mulher (sobretudo a mulher negra) na política. Também em 2018, já após o desenvolvimento da segunda campanha do Tupinambá Lambido, ocorreu o histórico protesto "Ele Não", liderado por mulheres em todo o Brasil e em algumas cidades do exterior, em repúdio ao então candidato à presidência do Brasil, Jair Bolsonaro, conhecido por suas ideias conservadoras e por declarações que insultam mulheres, negros e grupos minoritários. Esses dados mostram como os trabalhos do Tupinambá Lambido estão em sintonia com questões atuais, as urgências e as reivindicações da população.

A tomada das ruas é convocada por meio de um cartaz que apresenta a ilustração de uma pomba gira e a frase "O povo na rua", além de outro que apresenta o slogan "LUTA LIVRE", onde o "T" da palavra "luta" é grafado como um "L" invertido, podendo-se ler também "LULA LIVRE" - frase de ordem que tomou as ruas e redes sociais em manifestações promovidas por grupos de esquerda

\footnotetext{
12 Chamada por seus críticos de "Lei da Mordaça", a proposta limita a liberdade de expressão de professores e a atividade docente, sob pretexto de evitar propagandas político-partidárias e ideológicas. Os defensores do projeto, ligados a legendas políticas conservadoras, afirmam ser contrários ao que chamam de "doutrinação ideológica" nas escolas.
} 
que exigiam a liberdade do ex-presidente preso em 2018. Outro cartaz ilustra uma moeda de "1 irreal" de duas caras, com efígies do então presidente Michel Temer e do ex-presidente da Câmara Federal Eduardo Cunha, estampando duas faces da mesma moeda.

Além de sua projeção em espaços públicos, os cartazes do Tupinambá Lambido têm grande circulação na internet, onde adquirem dimensão de meme. Geralmente registradas por passantes, as imagens dos cartazes têm seu alcance ampliado graças ao potencial viral da internet.

Embora tenha surgido no contexto do impeachment de Dilma Rousseff, tomando como alvo os apoiadores e beneficiários desse processo, o Tupinambá Lambido continua atuando após a eleição presidencial de 2018 - que deu vitória ao candidato da direita Jair Messias Bolsonaro. O grupo pretende realizar novas campanhas, além de distribuir em festivais de cinemas internacionais o filme dirigido e editado por Lucas Parente, que documenta as ações do grupo.

O que define os coletivos estético-políticos é justamente sua indefinição. Seus agentes são considerados artistas por uns, ativistas por outros, ou ainda baderneiros, mas para eles as classificações pouco importam. A potência das ações aqui abordadas, sejam elas artísticas, ou políticas, ou as duas coisas ao mesmo tempo, encontra-se em sua capacidade de provocar o questionamento do status-quo. É na produção de visibilidades e de dissensos que os campos da estética e da política se cruzam.

\section{Referências bibliográficas}

BENJAMIN, Walter. A obra de arte na era de sua reprodutibilidade técnica. In: CAPISTRANO, Tadeu (org.). Benjamin e a obra de arte: técnica, imagem e percepção. Rio de Janeiro: Contraponto, 2012.

JACQUES, Paola Berenstein. Notas sobre espaço público e imagens da cidade. In: Arquitextos, São Paulo, n. 110.02, 2009.

RANCIÈRE, Jacques. A partilha do sensível: estética e política. São Paulo: EXO experimental org., Ed. 34, 2005.

RANCIĖRE, Jacques. O espectador emancipado. São Paulo: Editora WMF Martins Fontes, 2012.

SOUZA, Jessé. A radiografia do golpe: entenda como e por que você foi enganado. Rio de Janeiro: LeYa, 2016.

VASCONCELLOS, Jorge; PIMENTEL, Mariana. O que é uma ação estético-política? (um contramanifesto). In: Vazantes, Revista do Programa de Pós-Graduação em Artes do Instituto de Cultura e Artes, Ceará, n. 1, pp. 191-200, 2017. 